\title{
Monitoring Forest Cover Change and Fragmentation Using Remote Sensing and Landscape Metrics in Nyungwe-Kibira Park
}

\author{
Alphonse Kayiranga ${ }^{1,2,3}$, Alishir Kurban1,2*, Felix Ndayisaba ${ }^{1,2,3}$, Lamek Nahayo ${ }^{1,2,3}$,

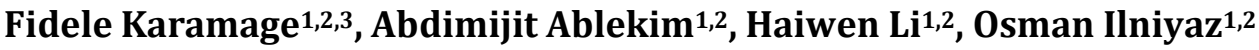

${ }^{1}$ State Key Laboratory of Desert and Oasis Ecology, Xinjiang Institute of Ecology and Geography, Chinese Academy of Sciences, Urumqi, China

${ }^{2}$ University of Chinese Academy of Sciences (UCAS), Beijing, China

${ }^{3}$ University of Lay Adventists of Kigali (UNILAK), Kigali, Rwanda

Email: kayiranga2020@yahoo.co.uk, *alishir@ms.xjb.ac.cn, davfelix@yahoo.fr, lameknahayo@gmail.com, fidelekar@gmail.com,

abdimijit@ms.xjb.ac.cn,243567875@qq.com,osmanjan99@163.com

How to cite this paper: Kayiranga, A., Kurban, A., Ndayisaba, F., Nahayo, L., Karamage, F., Ablekim, A., Li, H.W. and Ilniyaz, O. (2016) Monitoring Forest Cover Change and Fragmentation Using Remote Sensing and Landscape Metrics in Nyungwe-Kibira Park. Journal of Geoscience and Environment Protection, 4, 13-33.

http://dx.doi.org/10.4236/gep.2016.411003

Received: September 30, 2016

Accepted: November 1, 2016

Published: November 4, 2016

Copyright $\odot 2016$ by authors and Scientific Research Publishing Inc. This work is licensed under the Creative Commons Attribution International License (CC BY 4.0).

http://creativecommons.org/licenses/by/4.0/ (c) (i) Open Access

\section{Abstract}

The objective of this study was to evaluate forest cover change and forest degradation in Nyungwe-Kibira Park, a natural reserve straddling Rwanda and Burundi from 1986 to 2015. Landsat TM, ETM+ and 8OLI images of $30 \mathrm{~m}$ spatial resolution were used as primary datasets. Geographic Information System (GIS) techniques were used for forest cover mapping and landscape metrics were calculated by using FRAGSTATS software. Classification and change analysis of forest cover type and landscape patterns analysis were carried out. In addition, to analyze the correlated external disturbances, the buffer zone of $5 \mathrm{Km}$ was delineated outside the boundary of Nyungwe-Kibira Park. The results revealed that in among 5 land cover classes considered within the Park, the dominant one was dense forest class covering over $70 \%$ of the entire Park area while in the buffer zone cultivated and open land dominated at over $90 \%$ between the years 1986 and 2015. Change detection highlighted that within Nyungwe-Kibira forest, approximately $0.27 \%\left(4.97 \mathrm{Km}^{2}\right)$ of forest cover was cleared while $0.07 \%\left(1.22 \mathrm{Km}^{2}\right)$ was regenerated annually. In the buffer zone, the annual cleared forest cover was about $0.76 \%\left(13.02 \mathrm{Km}^{2}\right)$. The five landscape indices chosen at class level indicated a considerable fragmentation of forest inside the Park and the highest fragmentation in the buffer zone. Indeed, these results shed a bleak image over the future of the Nyungwe-Kibira forest that should be helpful for the policy-makers and managers of these natural parks to establish adequate policies to mitigate the forest loss and degradation by implementing quick and effective solutions. 


\section{Keywords}

Burundi, Forest Management, Landscape Analysis, Nyungwe-Kibira Park, Remote Sensing, Rwanda

\section{Introduction}

Tropical deforestation has been claimed as the primary contributor to global environmental change [1] which substantially threatens biodiversity, climate and livelihoods [2]. Deforestation in African tropics has recently accounted for over 23\% of forest loss worldwide [3]. Protected Areas (PAs) are found as a cornerstone of forest conservation policy in the developing countries [4]. The establishment of PAs is the main means to conserve forests and the associated ecological benefits including biodiversity habitats, hydrological sources and carbon sequestrations [5] [6]. In principle, PAs are established prior to stem forests clearing and degradation by restricting land-use changes and extractive activities within their borders [5]. However, in some countries, PAs are often established after forests have been cleared and degraded or yet the restrictions may not have been enforced because of political issues, financial insufficiency of their surrounding community, uncertainty of land tenure and conflicts within local communities. These factors have been inventoried among the reasons of large deforestation and forest degradation in Africa [7].

In central Africa, especially in Albertine Rift zone, deforestation is reported to have increased in several parks like in Uganda where, in the last-half century, the forest around Kibale National Park was cleared in attribution of charcoal production and the formerly impenetrable forest around Bwindi in South-West of Uganda vanished due to agricultural expansion [8]. In the Democratic Republic of Congo (DRC), thousands of hectares of forest have been cleared for mining activities, charcoal production and agricultural activities [9]. Rwanda and Burundi experienced similar cases of forest degradation, where the PAs have decreased in size as a result of agricultural expansion and ambiguously nudged forest boundaries [10]. As highlighted by Haino, M et al., [11], rapid population growth is correlated with the forest losses over the whole Albertine Rift region [12]. In the southern Albertine Rift landscape, the large forest of Nyungwe-Kibira Park, which is rich in biodiversity, was reported to be protection sensitive [13]. However, as the forest is enclosed by public and private landholdings, it has been reported that agricultural expansion, legal and illegal timber harvesting, unclear land tenure system are the main constraints to this forest conservation [14]. Despite a number of studies which have been carried out focusing on forest loss in the NyungweKibira corridor [14] [15], little to zero ranging emphasis has been put on highlighting the spatial and temporal patterns of forest cover changes within and outside the boundaries, especially within the last three decades.

Therefore, historical forest cover changes and landscape scale status could be as- 
sessed to provide critical information for future planning [16]. Hence, spatial and temporal pattern research is needed to assess the net effects on the protected areas on both forest cover change and the analysis of its landscape scale generally [17]. The main issue here is to identify the forest cover change specifically the rate of deforestation and degradation and rate of forest regeneration. Analysis of landscape scale is also necessary to distinguish the state of patches of forest and understand the spatial temporal complexity of forest cover fragments. Satellite-based tools have been proven as the appropriate way to study forest cover changes due to their capacity to cover a large-scale area and to transcend country borders when the study is carried out on a transboundary scale. Additionally, it provides the time-series information from the start to end points of the period [18]. In that framework, the generation of forest cover change cartography from the satellite image processing is one of the most substantial and widespread remote sensing applications [19]. From this cartography, the possibility to obtain and analyze the spatial patterns of forest cover in a region is higher. Satellite based remotely sensed data have been widely proven to be most useful in landscape ecology studies and in understanding the ecological processes with strong spatial temporal components [20]. Landsat data have been mostly used for determining forest cover and measuring forest cover changes and the rate of change [21] [22]. Therefore, the objectives of this study are 1) to describe the land cover changes in Nyungwe-Kibira forest from 1986 to 2015 2) to monitor the forest cover changes and 3) to analyze landscape dynamics within and outside Nyungwe-Kibira Park boundary.

\section{Materials and Methods}

\subsection{Study Area}

Nyungwe-Kibira forest (Figure 1) was the first gazetted forest reserve by the Belgian colonial administration in 1933 combining Nyungwe forest and the Kibira forest. It lies within the border at the South-West of Rwanda and stretches to the Kibira National Park in the North-West of Burundi and is counted among the located tropical mountain rainforests of East-Africa [23]. Between 1962 and 1988 the massif of Nyungwe-Kibira forest was classified as the straddle of Nile and Congo River Basin and the principal Rwanda's water supply [24]. In 1996 Kibira (North western Burundi) was officially declared a National Park while its conjoint Nyungwe in Rwanda was officially recognized as a National Park in 2005 [24] [25]. Nyungwe-Kibira forest covers an approximate area of $1600 \mathrm{Km}^{2}$ and is characterized by a tropical climate with daily temperatures varying between $14.4^{\circ} \mathrm{C}$ to $19.9^{\circ} \mathrm{C}$ and a mean annual rainfall of $1744 \mathrm{~mm}$ [26] [27] with two seasons, dry and rainy [28]. This forest is rich in both flora and fauna biodiversity; about 644 plant species, 98 species of mammals and 43 bird families, along more than 200 species, were identified within this forest as reported by the United Nations Food and Agriculture Organization (FAO) in its document repository 2010 [29]. The study site is situated on the altitude ranging from 1012 to 2944 meters above sea level (m.a.s.l) (Figure 1). 


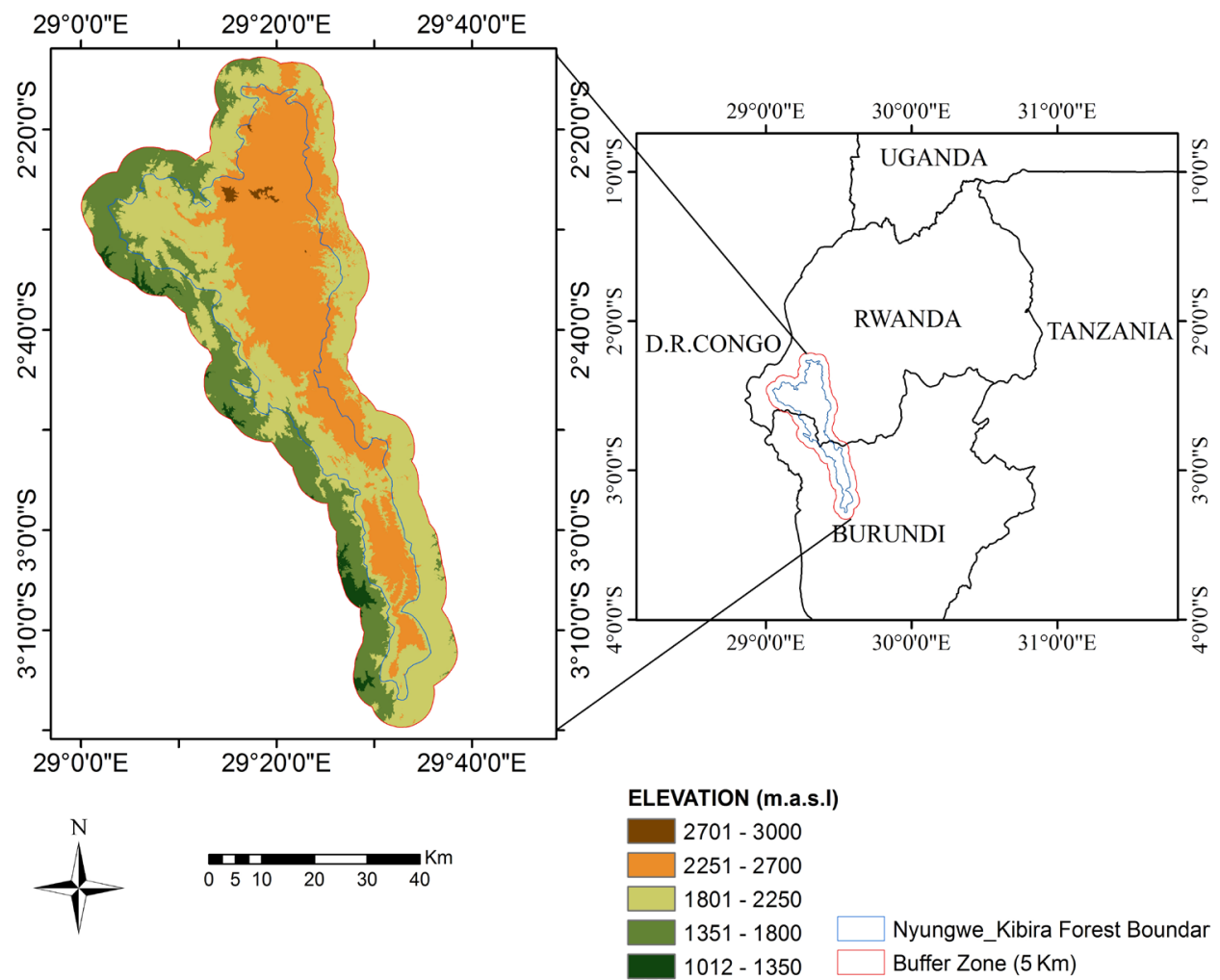

Figure 1. Location map of Nyungwe-Kibira forest. The extension area of the park was 1686.5 $\mathrm{Km}^{2}$ whereas that of the buffer zone was $1700 \mathrm{Km}^{2}$ calculated for stratified $5 \mathrm{Km}$ around the park.

\subsection{Data Acquisition}

Landsat Thematic Mapper (TM), Landsat Enhanced Thematic Mapper Plus (ETM+) and Landsat 8 Operational Land Imager (OLI) and Thermal Infrared Sensor (TIRS) remotely sensed data were used to map land cover change in Nyungwe-Kibira forest and its landscape. Thus, Landsat satellite images for 1986, 1990, 1995, 2000, 2010 and 2015 were acquired from the U.S Geological Survey (USGS) to evaluate the change in forest cover from 1986 to 2015 in 5 years time-steps. Good quality scenes from Landsat 172 path and 61 row were primarily targeted during this period. However, due to the obscure of clouds over the forests cover and high mountains on the surface of the study area, which may induce changes in surface features' spectral characteristics, some images were deemed unusable. Thus, images with the lowest cloud cover percentage were screened. Images either full of haze and clouds or affected by the Scan Line Corrector (SLC-off) defections were disqualified; hence, 2005 images and scenes prior to 1986 were precluded from the usable dataset in this particular study. Furthermore, in order to improve the discrimination during classification, only dry season images were selected since rainy season images in tropical areas are more complex to distinguish vegetation cover classes because of higher greenness [30].

Shuttle Radar Topography Mission (SRTM) Digital Elevation Model (DEM) version 
4 was used to derive the slopes and the aspects. The two tiles of DEM of $30 \mathrm{~m}$ spatial resolution have been downloaded from the CGIAR Consortium for Spatial Information (CGIAR-CSI)'s website, (http://srtm.csi.cgiar.org/selection/listImages.asp); one at Center point latitude of $2^{\circ} 50^{\prime}$ South and Longitude of $27^{\circ} 50^{\prime}$ East and the other at Latitude of $2^{\circ} 50^{\prime}$ South and Longitude of $32^{\circ} 50^{\prime}$ East. This SRTM data is available as 1 arc second (approx. $30 \mathrm{~m}$ resolution) DEMs to the equator and $1 \times 1$ degrees tiles in WGS84 Geoid reference datum. This dataset has been chosen due to its finer spatial resolution that closely matches with the geo-referenced Landsat images and at comparable accuracies [30]. Nyungwe-Kibira Park boundary was delineated based on the "Atlas change of our environment Program-UNEP" [31]. And from this boundary, we created a $5 \mathrm{Km}$ buffer zone to describe the surrounding landscape. The buffer zone has been established to evaluate the amount of pressures (socio-economic effects) coming from the forest's vicinity [32]. This method has been applied in other studies and the 5 $\mathrm{Km}$ distance has been hypothesized as enough to analyze the external effects to the forest cover [32] [33] [34].

\subsection{Image Processing}

Image processing was performed using ENVI5.2 and ArcGis10.2 into three phases: 1) pre-processing; 2) image classification; 3) post-classification and change detection. In the first phase radiometric and atmospheric corrections have been performed to correct atmospheric conditions from sensors' scanning errors as well as distortions from solar angle and sensors' angle in the Landsat images. DEM, Slope and Aspect were used for topographical correction to compensate the high topography and to eliminate classification errors. All images from each study year were clipped to match with the study area and buffer zone boundaries.

In the second phase, image classification and land cover change detection were performed. Supervised classification method was applied to six Landsat images (1986, 1990, 1995, 2000, 2010 and 2015) using the Maximum likelihood Classification method (MLC) a well-known parametric classifier for supervised classification [35]. Training samples were independently selected from each image in order to produce related spectral signatures that depicted five classes in the final classification (dense forest, dispersed forest and shrub, water, perennial croplands (tea plantation) and other agricultural land including cultivated and open lands). The third phase contained the post classification process in which kernel size of $7 \times 7$ majority algorithm was applied and used to smooth and eliminate noise in classes. Moreover, change detection was performed to assess the changes through the entire land cover during the study period for both the Park area and buffer zone. Land cover maps were derived from each year of study. To address the concern of detecting forest cover change in Nyungwe-Kibira Park from 1986 to 2015, land cover types of interest were forested areas (dense forest and dispersed forest). In this case, the forest classes were combined into one class called forest cover and was assigned to the values of " 1 " and the combination of all other 
classes was named "Non-forest" and assigned to the values of "0" to create a binary image in ArcGIS 10.2 where the processes were applied to all classified images (19862015). Image differencing was then undertaken and recent scenes were subtracted from the older ones to detect spatial and temporal patterns of forest changes in time using Raster calculator tool developed in ArcGIS 10.2 to separate and statistically evaluate the forested area by non-forest areas and estimate forest losses (deforestation) and forest gains (regeneration).

\subsection{Accuracy Assessment}

The accuracy assessment was performed to determine the quality of information obtained from data analysis and classification processes of each images [36]. The overall, kappa, producer and user accuracies of land cover and land use map were developed from Landsat data by comparing the land cover results with Google Earth (GE) based on Very High Resolution Satellite Images (VHRSI). Systematic initial reference points were geo-referenced on GE precisely according to the field knowledge of the study area. Similar studies applied this particular approach in the recent past and it was proven successful [37]. A total number of 320 points were stratified from the available Very high resolution images on GE (for 2010 and 2015) where at least 75 points for the classes covering big areas and 30 points for those covering small areas were selected. The points were evenly distributed and over-scattered on their corresponding land cover maps for accuracy assessment. For the remaining images (1986-2000), we used the true color composite image band 3 (red band), 2 (green band), and 1 (blue band) for the same Landsat images (Landsat TM). This method is always used in absence of field data and higher resolution images or ground truth data [17].

\subsection{Landscape Metrics Measurement and the Evaluation of Landscape Patterns at Class Level}

To quantitatively analyze Nyungwe-Kibira forest and its surrounding landscape's forest fragmentation, the landscape metrics at landscape and class levels were applied. The five indices were calculated from FRAGSTAT4.2 for both the Park and buffer zone to further explore the degree of landscape cover types and spatial dispersion. In this study, we only focused on forest cover type which was the main focus of interest for this research. The indices were evaluated in each year based on the set of landscape range values as shown in Table 1.

The process of quantifying the habitat fragmentation involves both loss and change in habitat pattern. The fragmentation of landscape by habitat types would go from $100 \%$ to $0 \%$ [39]. We found that the indices indicated in Table 1 were suitable to the landscape analysis at class level in conformity with the objectives of this study, consisting of the assessment of forest degradation inside Nyungwe-Kibira Park and the surrounding buffer zone. 
Table 1. Landscape metrics at class level used to quantify forest cover in Nyungwe-Kibira corridor and the surrounding landscape ( $5 \mathrm{Km}$ buffer zone).

\begin{tabular}{|c|c|}
\hline Indices and units & Description \\
\hline Number of Patches-NP & $\begin{array}{c}\mathrm{NP}>1 \text {, without limit, } \mathrm{NP}=1 \text { when a landscape or class type } \\
\text { contains one patch, number of patches corresponding } \\
\text { to class type at a landscape. }\end{array}$ \\
\hline $\begin{array}{l}\text { Patch Density-PD } \\
\text { (Patches/100 ha) }\end{array}$ & $\begin{array}{l}\text { Patches corresponding to the total forest cover divided } \\
\text { by the total Area multiplied by } 100 \text {. If forest class } \\
\text { represents a greater PD, it indicates that it is } \\
\text { subdivided into many patches and thus } \\
\text { could be considered as fragmented. }\end{array}$ \\
\hline Mean Patch Size-MPS (ha) & $\begin{array}{l}\text { The average area of patches corresponding to the } \\
\text { forest cover type. Greater MPS indicate } \\
\text { slightly fragmented forests. }\end{array}$ \\
\hline $\begin{array}{l}\text { Interspersion Juxtaposition } \\
\text { Index-IJI (\%) }\end{array}$ & $\begin{array}{l}\text { IJI } \geq 1 \leq 100, \text { IJI measures patch adjacency. } \\
\text { IJI approaches } 100 \text { when all patch types are } \\
\text { equally adjacent to each other. }\end{array}$ \\
\hline $\begin{array}{c}\text { Mean-Proximity } \\
\text { Index-PROX_MN (m) }\end{array}$ & $\begin{array}{c}\text { PROX_MN } \geq 0 \text {, PROX_MN }=0 \text { if a patch has no neighbors } \\
\text { of the same type at specific radius. Lower number of patches } \\
\text { at a specified radius distance signifies the } \\
\text { state of fragmentation. }\end{array}$ \\
\hline
\end{tabular}

Source: FRAGSTATS help [38].

\section{Results}

\subsection{Spatial Patterns of Land Cover Change}

Land cover classification results showed that the dense forest (intact forest) over 70\% remained stable from 1986 to 2010 while the high forest cover reduction was recorded in 2015 falling to $63.73 \%$ inside Nyungwe-Kibira Park. Moreover, the dispersed forest cover became larger in 2015; expanding to cover about $18.73 \%$ of Nyungwe-Kibira Park total area compared to its former size (13\%) in 1986. This degradation of forest cover increased relatively with the increase of cultivated and open lands which largely expanded from $1.5 \%$ in 1986 to $16.40 \%$ in 2015 . Tea plantation, which was a predominant perennial crop in Nyungwe-Kibira corridor relatively decreased with the decrease of dense forest. The statistics representing changes within the Park are totally different from the results found within 5 kilometers in the landscape surrounding the Park (Buffer zone). Intensive agriculture land use was highly dominating the land cover (over $70 \%$ of occupancy from 1986 to 1995, growing to over $80 \%$ from 2000 to 2010 and reaching over $90 \%$ in 2015). Perennial crop was also characterized by an increasing cover area, expanding from $0.6 \%$ in 1986 to over $1 \%$ of the total area in 2015 as shown in Table 2 and Figure 2. 

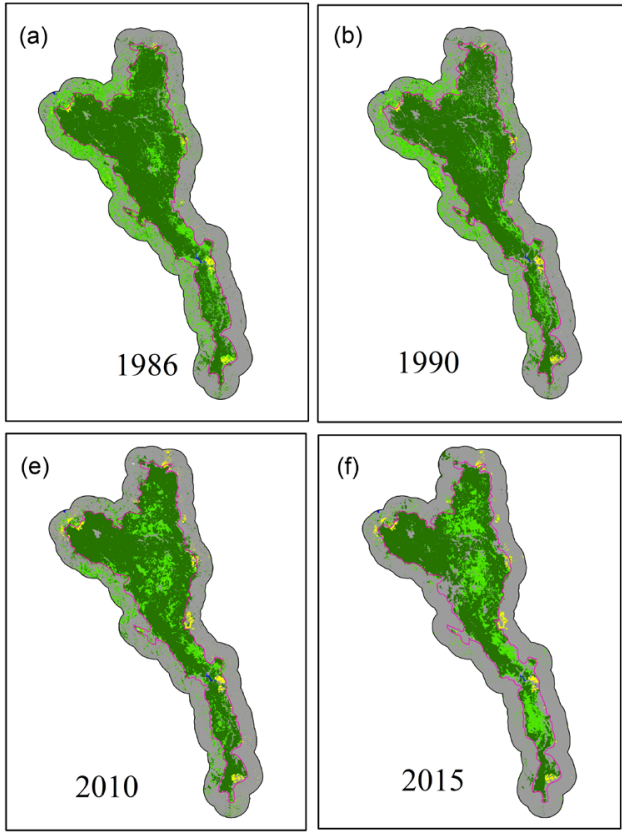
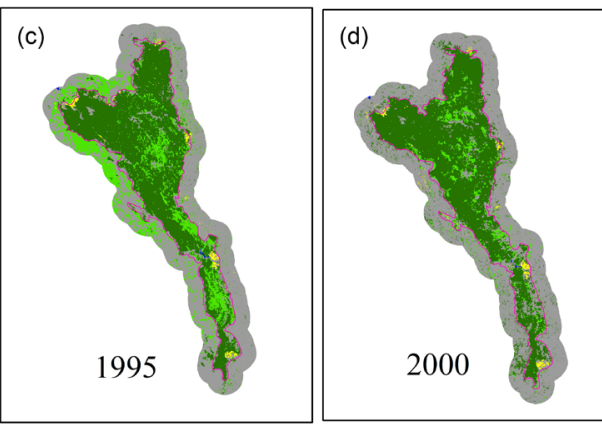

\section{Legend}

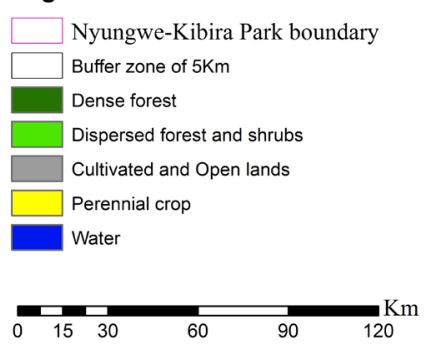

Figure 2. Thematic map showing land cover within Nyungwe-Kibira Park and within $5 \mathrm{Km}$ of buffer zone in landscape outside the Park boundary from 1986 to 2015.

Table 2. Spatial distribution of Land Cover change results for Nyungwe-Kibira Park between 1986 and 2015 within and Outside the Park (Buffer zone within 5 Kilometers).

\begin{tabular}{cccccccccccccc}
\hline \multirow{2}{*}{$\begin{array}{c}\text { LC } \\
\text { classes }\end{array}$} & \multicolumn{4}{c}{ Park (\% Area) } \\
\cline { 2 - 12 } & 1986 & 1990 & 1995 & 2000 & 2010 & 2015 & 1986 & 1990 & 1995 & 2000 & 2010 & 2015 \\
\hline 1 & 78.1 & 76.0 & 73.3 & 76.4 & 77.0 & 63.8 & 5.1 & 4.0 & 2.9 & 7.2 & 6.0 & 2.3 \\
2 & 13.0 & 6.7 & 13.6 & 8.9 & 13.8 & 18.7 & 22.6 & 20.6 & 19.6 & 2.6 & 7.5 & 3.2 \\
3 & 1.5 & 16.0 & 11.6 & 13.5 & 7.9 & 16.4 & 71.7 & 74.8 & 77.0 & 89.7 & 84.7 & 93.1 \\
4 & 1.3 & 1.3 & 1.4 & 1.1 & 1.2 & 1.0 & 0.6 & 0.6 & 0.4 & 0.5 & 1.8 & 1.3 \\
5 & 0.1 & 0.1 & 0.1 & 0.1 & 0.1 & 0.1 & 0.0 & 0.0 & 0.0 & 0.0 & 0.0 & 0.1 \\
\hline
\end{tabular}

1: Dense Forest, 2: Dispersed and shrub, 3: Cultivated and Open land, 4: Perennial crop and 5: Water.

\subsection{Accuracy and Validation}

The accuracy assessment was systematically performed for each image; the results revealed that the overall accuracy and kappa coefficients represented for each classified image were greater than 75\% for all images from 1986 to 2015. Error matrix was used to determine producer's accuracy and user's accuracy among the Land Cover (LC) classes. The results from producer and user's accuracy were represented for variation among LC classes and periods, however, the confusion was caused by the increase of omission and commission errors only in Cultivated and open land which was at some instances confused with dispersed forest and shrub class. The classification accuracies are summarized in Table 3. 
Table 3. Summary of accuracy assessment results.

\begin{tabular}{cccccccccccccc}
\hline \multirow{2}{*}{$\begin{array}{c}\text { LC } \\
\text { Classes }\end{array}$} & \multicolumn{2}{c}{1986} & \multicolumn{2}{c}{1990} & \multicolumn{2}{c}{1995} & \multicolumn{2}{c}{2000} & \multicolumn{2}{c}{2010} & \multicolumn{2}{c}{2015} \\
\cline { 2 - 12 } & P.A & U.A & P.A & U.A & P.A & U.A & P.A & U.A & P.A & U.A & P.A & U.A \\
\hline 1 & 84.09 & 88.70 & 76.54 & 78.23 & 87.32 & 89.15 & 81.36 & 73.39 & 71.81 & 85.76 & 87.68 & 83.26 \\
2 & 88.03 & 92.01 & 86.45 & 79.12 & 82.67 & 87.34 & 69.2 & 70.12 & 80.04 & 73.69 & 84.35 & 86.28 \\
3 & 85.01 & 79.77 & 78.65 & 80.67 & 76.23 & 78.12 & 75.28 & 72.53 & 79.92 & 72.12 & 77.15 & 76.34 \\
4 & 90.81 & 95.06 & 92.54 & 95.23 & 85.72 & 87.02 & 76.59 & 72.32 & 80.25 & 82.03 & 82.73 & 81.73 \\
5 & 95.54 & 96.63 & 87.34 & 85.09 & 86.18 & 86.41 & 77.1 & 86.21 & 75.32 & 78.54 & 78.23 & 79.02 \\
O.A & $78.0 \%$ & $79.6 \%$ & $81.2 \%$ & 80.6 & $86.03 \%$ & $83.28 \%$ \\
Kappa & $79.21 \%$ & $77.72 \%$ & $84.06 \%$ & $87.54 \%$ & $87.19 \%$ & $88.09 \%$ \\
\hline
\end{tabular}

1: Dense Forest, 2: Dispersed and shrub, 3: Cultivated and Open land, 4: Perennial crop and 5: Water, P.A: Producer's Accuracy in percentage (\%) and U.A: User's Accuracy in percentage (\%), O.A: Overall Accuracy and Kappa: Kappa coefficient.

\subsection{Land Cover Change Detection in Nyungwe-Kibira Park and in Surrounding Landscape-Scale}

Within the Park and the outside landscape, the land cover classification highlighted different scenarios according to which changes were high in the dominant Land cover classes (Forest and cultivated/open land). From 1986 to 2015, dense forest reduced by approximately $14.32 \%$ within the Park while a decline of $5.04 \%$ was observed outside the Park (in buffer zone). The declines of forest was boasted by the great increase of cultivated or open lands where the open land and agriculture practices occurring within the Park's boundaries greatly increased up to $8.5 \%$ inside and highly increased up to $21.36 \%$ outside the Park. The statistical trends of the resulting land cover changes are illustrated in Table 4.

Table 4. Land cover change detection within Nyungwe-Kibira Park and its surrounding buffer zone, (negative $=$ decrease, positive values $=$ increase).

\begin{tabular}{ccccccccccc}
\hline \multirow{2}{*}{ Period } & \multicolumn{9}{c}{ Park (Area in \%) } & \multicolumn{7}{c}{ Buffer zone (Area in \%) } \\
\cline { 2 - 11 } & 1 & 2 & 3 & 4 & 5 & 1 & 2 & 3 & 4 & 5 \\
\hline $1986-1990$ & -2.11 & -6.33 & 8.53 & -0.04 & -0.04 & -1.12 & -1.95 & 3.06 & 0.02 & 0.00 \\
$1990-1995$ & -2.65 & 6.94 & -4.44 & 0.15 & 0.01 & -1.04 & -0.96 & 2.22 & -0.21 & -0.01 \\
$1995-2000$ & 3.05 & -4.65 & 1.95 & -0.33 & -0.03 & 4.25 & -17.06 & 12.66 & 0.14 & 0.00 \\
$2000-2010$ & 0.67 & 4.82 & -5.63 & 0.12 & 0.03 & -1.21 & 4.94 & -5.00 & 1.28 & 0.00 \\
$2010-2015$ & -13.27 & 4.98 & 8.52 & -0.18 & -0.04 & -3.68 & -4.29 & 8.42 & -0.47 & 0.02 \\
$1986-2015$ & -14.32 & 5.75 & 8.93 & -0.29 & -0.08 & -5.04 & -19.32 & 21.36 & 0.76 & 0.01 \\
\hline
\end{tabular}

1: Dense Forest, 2: Dispersed and shrub, 3: Cultivated and Open land, 4: Perennial crop and 5: Water. 


\subsubsection{Forest Covers Change Detection at Nyungwe-Kibira Corridor (Within and Outside the Park)}

Approximately 8\% $\left(144.42 \mathrm{Km}^{2}\right)$ of forest was lost within Nyungwe and Kibira National

Parks between 1986 and 2015 and a highest decrease of forest, about 22.12\%, was recorded in the outer areas (buffer zone). The periods from 1990 to 1995 and 2000 to 2010 were characterized by the expansion of forest area inside the park. The magnitude of expansion was approximately evaluated at $4.29 \%$ and $5.48 \%\left(72.3 \mathrm{Km}^{2}\right.$ and $\left.92.5 \mathrm{Km}^{2}\right)$ respectively. However, within the buffer zone the increase in forest cover was only registered during the period between 2000 and 2010 by approximately $3.73 \%\left(62.73 \mathrm{Km}^{2}\right)$ while the other time-series represented negative values as illustrated in Figure 3 and Figure 4 .

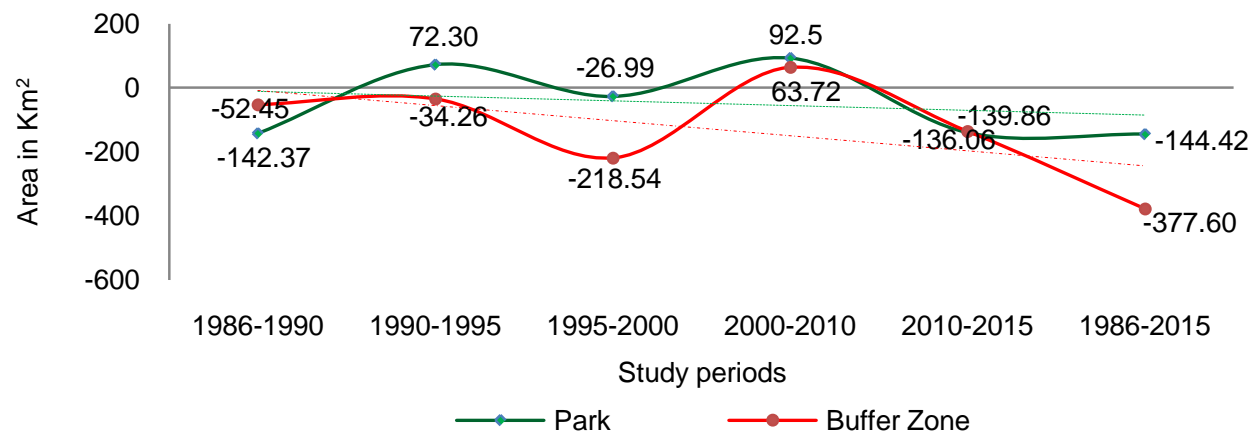

Figure 3. Forest cover change trends within Nyungwe-Kibira Park and in buffer zone (negative values $=$ decrease, positive values $=$ increase $($ values expressed in square $\mathrm{Km})$.
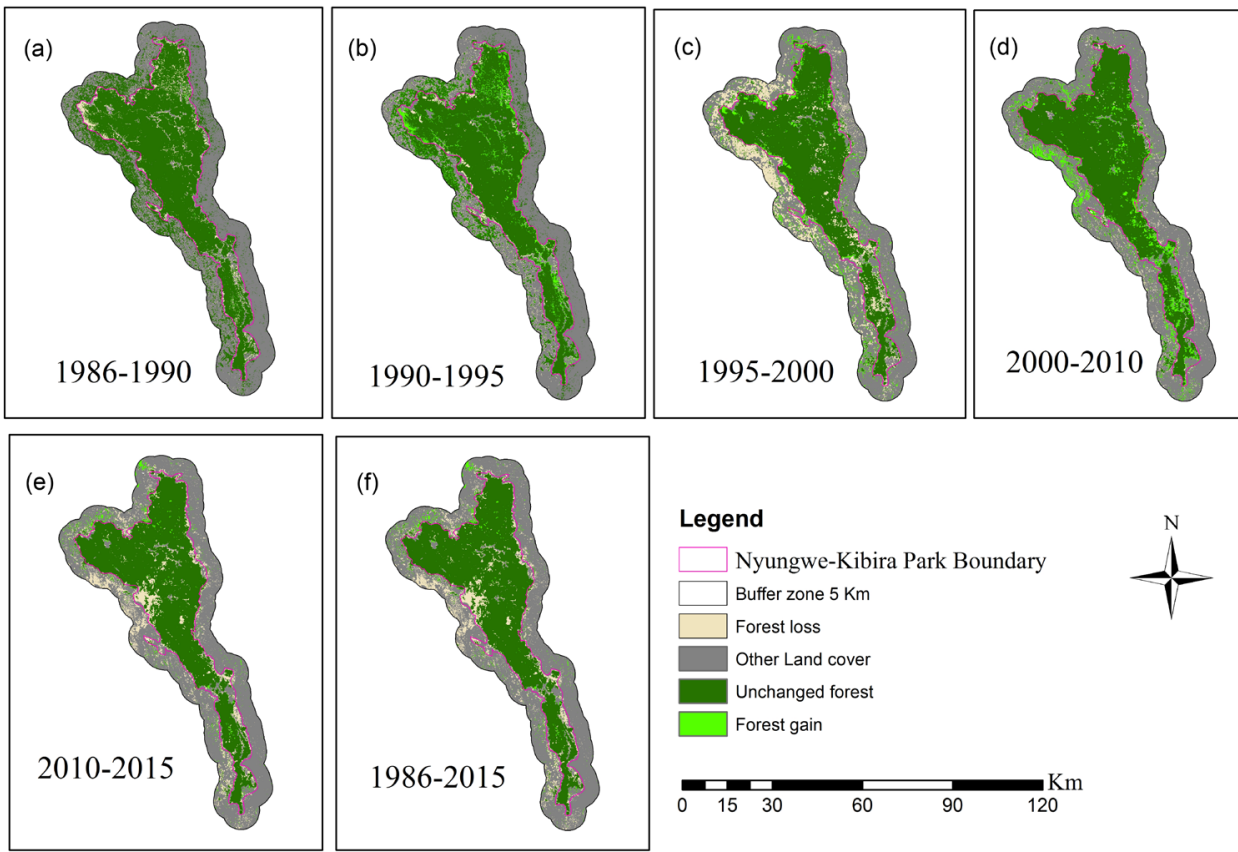

Figure 4. Forest cover change results; change in forest cover was quantified within Park and in the buffer zone by differentiating the adjacent periods, the latest period minus the older in the entire study period. Areas of Forest lost (deforestation) were depicted in tan color. Forest extent gained (reforestation) was depicted in very light-green color. 


\subsubsection{Annual Rate of Forest Cover Change within the Park}

The changes in forest cover within the Park were interchangeably represented by losses (deforestation) and gains (forest regeneration). The results from the analysis showed that between 1986 and 2015 the deforested and degraded area was approximately $10.68 \%$ and the regenerated forest was approximately $2.14 \%$ over the entire forest cover size inside Nyungwe-Kibira Park. This study has used Pyravaud's formula [40] that provides a standardized method to calculate the net annual rate of change from forest cover at different time periods while reducing confusion and misinterpretation. The annual rate of change abbreviated as " $r$ " is extrapolated for each time period as follows:

$$
\mathrm{r}=\left(\frac{1}{\mathrm{t} 2-\mathrm{t} 1}\right) \ln \left(\frac{\mathrm{A} 2}{\mathrm{~A} 1}\right)
$$

where $\mathrm{A} 1$ and $\mathrm{A} 2$ represent the area of forest cover at time one (t1) and time two (t2) respectively.

It has been revealed that an annual rate of $0.4 \%$ of initial forest cover was deforested/ degraded while an average of $0.07 \%$ of forest was regenerated. These statistical trends imply that $8 \%$ of the forest cover was cleared within Nyungwe-Kibira Park where about $0.27 \%$ of forest which is equal to $4.97 \mathrm{Km}^{2}$ was lost annually between 1986 and 2015 . Despite the greater loss found compared to the gain of forest cover inside the Park during the entire study period, this situation was balanced by the middle periods that represented higher gains than losses; for instance, we found that between 1990 and 1995 forest cover loss was $3.63 \%$ while forest gain was $7.82 \%$ and during the period between 2000 and 2010 , the loss was $1.72 \%$ against $7.17 \%$ of gain, this expressed that the rate of deforestation was less than forest regeneration only in these mentioned periods as shown in Figure 3 and Figure 4.

\subsubsection{Annual Rate of Forest Cover Change in Buffer Zone}

Forest cover quantification within $5 \mathrm{~km}$ outside the park depicted the highest loss of approximately $22.11 \%$ over 29 years. This means that $0.76 \%$ of forest cover was lost annually, notwithstanding a moderate increase of $5.45 \%\left(63.72 \mathrm{Km}^{2}\right)$ registered during the period from 2000 to 2010 . The major losses incurred during the other two intervening periods (1995-2000 and 2010-2015) magnified the loss in total forest cover throughout the entire study period. Hence, the overall decline of $377.60 \mathrm{Km}^{2}$ in total forest cover originated from the mixed temporal patterns (see Figure 3 and Figure 4).

\subsection{Estimating Degradation of Forest in Nyungwe-Kibira Park and the Surroundings, Including Landscape Analysis}

The analysis per class level was done to evaluate the ecological landscape measurement within Nyungwe-Kibira forest and in buffer zone of $5 \mathrm{Km}$ outside the Park, using five indices to qualitatively and quantitatively analyze the spatial temporal patterns of change in forest cover type for 1986, 1990, 1995, 2000, 2010 and 2015. The indices illustrated in Table 1 were calculated and the results were reported in Table 5 and Table 6 shown below. 
Table 5. Forest degradation estimates within Nyungwe-Kibira Park.

\begin{tabular}{cccccc}
\hline & \multicolumn{5}{c}{ Indices } \\
\cline { 2 - 6 } Year & NP & $\begin{array}{c}\text { PD } \\
(\text { Patches/100 ha })\end{array}$ & $\begin{array}{c}\text { MPS } \\
(\text { ha })\end{array}$ & $\begin{array}{c}\text { PROX_MN } \\
(\mathrm{m})\end{array}$ & $\begin{array}{c}\text { IJI } \\
(\%)\end{array}$ \\
\hline 1986 & 707 & 0.42 & 186.17 & $90,104.42$ & 52.32 \\
1990 & 689 & 0.41 & 185.49 & $40,260.32$ & 60.69 \\
1995 & 522 & 0.31 & 236.21 & $73,999.08$ & 54.47 \\
2000 & 350 & 0.21 & 367.17 & $12,027.14$ & 57.34 \\
2010 & 291 & 0.17 & 445.32 & $37,341.33$ & 45.55 \\
\hline
\end{tabular}

Table 6. Forest degradation estimates within the buffer zone outside Nyungwe-Kibira Park.

\begin{tabular}{cccccc}
\hline & \multicolumn{5}{c}{ Indices } \\
\cline { 2 - 6 } Year & NP & $\begin{array}{c}\text { PD } \\
\text { (Patches/100 ha) }\end{array}$ & $\begin{array}{c}\text { MPS } \\
(\text { ha })\end{array}$ & $\begin{array}{c}\text { PROX_MN } \\
(\mathrm{m})\end{array}$ & $\begin{array}{c}\text { IJI } \\
(\%)\end{array}$ \\
\hline 1986 & 6343 & 3.72 & 1.37 & 964.51 & 53.20 \\
1990 & 4223 & 2.47 & 1.61 & 223.03 & 54.53 \\
1995 & 1506 & 0.88 & 1.88 & 102.37 & 58.01 \\
2000 & 4023 & 2.36 & 3.05 & 14.56 & 34.13 \\
2010 & 5078 & 2.98 & 2.01 & 47.46 & 50.37 \\
2015 & 964 & 0.57 & 4.06 & 13.14 & 60.77 \\
\hline
\end{tabular}

NP: Number of Patches, PD: Patch density, MPS: Mean Patch Size, PROX_MN: Mean Proximity Index, IJI: Interspersion Juxtaposition Index.

The results of forest cover type analyzed within and outside Nyungwe-Kibira Park represented a high variation along the metric indices which were used. Significant discrepancies were depicted between the forest covers inside and outside the park. NP (the number of patches) highly decreased in the period from 1986 to 2015 and these changes were proportional to the changes in Patch density and size in both inside and outside the park. MPS values found were greater within Nyungwe-kibira Park while found in the buffer zone were lower; signaling out the severe fragmentation outside and the slight fragmentation inside the park. These levels of forest degradation outside the park can also be emphasized by the patch density analysis. The results from this analysis indicated that patch density (PD) in forest within Park was lower at $\mathrm{PD}<1$; meaning that forest patch was not subdivided while in buffer zone due to high deforestation and degradation, $\mathrm{PD}$ is higher at $\mathrm{PD}>1$. This expresses that forest outside the Park boundary was highly subdivided into many patches which represent a high forest fragmentation 
as illustrated in Table 5 and Table 6 above.

\section{Discussion}

Analysis of forest cover changes and landscape dynamics in Nyungwe-Kibira Park through time series as well as Land Cover mapping revealed that the interchanges among the cover types were highly rendered by changes of forest cover from 1986 to 2015. The results revealed a moderate deforestation inside the Park where approximately $8 \%\left(144.42 \mathrm{Km}^{2}\right)$ was cleared within the Park. This expresses an annual loss of $4.97 \mathrm{Km}^{2}$ (0.27\%) from 1986 to 2015 (Figure 3 and Figure 4). This loss in forest cover inside the Park has been converted into different classes among the Land Cover types found in the Nyungwe-Kibira Park after classification especially "open lands". The situation inside the Park was totally different from the outer parts $(5 \mathrm{Km}$ buffer zone delineated outside the Park) which were characterized by extensive deforestation/degradation. Geo-statistical analysis indicated that approximately $22.11 \%\left(377.60 \mathrm{Km}^{2}\right)$ of forest cover type in the buffer zone was lost (deforested and degraded) from 1986 to 2015; implying to an approximate annual loss of $0.76 \%$ equivalent to $17.06 \mathrm{Km}^{2}$ (Figure 3 and Figure 4). This high deforestation rate in the area surrounding Nyungwe-Kibira was associated to the intensive agriculture that was approximately $71.3 \%$ in 1986 , before climbing to $93.1 \%$ in 2015 . This analysis highlighted that conversions among the land cover types basically triggered the reduction of forest cover size both within and outside the park. Given that the major transitions mainly occurred among three classes during the entire study period, we analyzed the land cover transitions inside and outside the park; the results indicated that inside the park, dense forest as the preponderant cover type (61.65\%) lost around $9.37 \%\left(158.08 \mathrm{Km}^{2}\right)$ being transformed into dispersed forest (degraded) and $6 \%\left(101.11 \mathrm{~km}^{2}\right)$ was turned into agriculture and/or open lands. The transitions among classes also occurred in all years spanning the study period and exerted a certain influence on forest cover change (deforestation/degradation and regeneration). In buffer zone, $0.45 \%\left(7.72 \mathrm{Km}^{2}\right)$ of dense forest was shifted to disperse forest, $3.79 \%\left(64.71 \mathrm{Km}^{2}\right)$ were cleared by agricultural activities and/or open lands, whereas disperse forests cover also retreated by $20.1 \%\left(343.05 \mathrm{Km}^{2}\right)$, giving way to intensive agriculture in buffer zone and forests clear cutting for timber and nontimber wood where agriculture is mostly dominant at over 70\% (Appendix A Table 7).

Due to landscape analysis at class level, the results revealed that the values of MPS increased proportionally with decrease of NP, lowest MPS values were calculated in the buffer zone opposite to the MPS found inside the Park during the whole study period (1986-2015). The analysis of MPS indicated that forest inside the Park was slightly fragmented as reported by previous studies [18] [41] [42]. Similar investigations highlighted that the greater MPS the lower degradation; conforming to the findings of this study especially the analysis of number of patches and edge density (Table 5). Normally due to the lowest change found in forest cover, without external circumstances, the inner forest inside the Park could have remained in its intact state. However NP revealed that forest was affected and slightly patched. 
Despite the lowest level of forest fragmentation found inside the Park, in the buffer zone MPS were represented by the lower values which indicated the high level of forest fragmentation; hence, in buffer zone, the forest was highly fragmented; following the assumption that the greater the number of patches the greater subdivision of forest cover may have incurred (Table 6). Association between forest and other land cover types using Interspersion Juxtaposition Index (IJI) as suggested by Zhou, Q. et al. [43] as the most useful way to describe spatial association between land cover classes was applied in this study to assume the associability between forest patches, and the results indicated a high correlation between IJI and forest cover losses in both inside the park and in buffer zone. The correlation of forest change and IJI was high with $\mathrm{R}^{2}=0.756$ and $\mathrm{P}$-value $=0.0244$ inside the park and $\mathrm{R}^{2}=0.6278$ and $\mathrm{P}$-value $=0.0602$ in buffer zone. The IJI has changed apparently each year, which implied the spatial forest patches adjacency changes where the calculated IJI showed medium variations both inside the park and in buffer zone (Figure 5).

The aggregation of forest patches also was analyzed both inside the park and in buffer zone to check for the number of forest patches that may have clumped within a search radius and the threshold distance of 100 meters. PROX-MN is the most commonly used metric to evaluate the inter-patches distance and the level of isolation as reported by Bortoleto et al., [44]. This method helped to verify the degradation of forest in view of fragmentation due to spatial understanding of the number of forest patches located into 100 meters where greater PROX-MN signifies closer patches in which implying less fragmentation. The results in Figure 6(a) and Figure 6(b) illustrated brisk forest degradation in buffer zone (Figure 6(b)) and vague changes which also led to degradation inside the Park (Figure 6(a)).

Nyungwe-Kibira Park is a protected natural reserve and the measures to preserve its rich biodiversity are initiated by both Burundi and Rwanda governments [45] and the park is registered as a protected area by the United Nations Environmental Program (UNEP) [46]. However, the results of this study highlighted considerable forest losses (deforestation/degradation) over the last few decades. Despite the entire protection protocol governing the park, several factors may have contributed to the losses observed including but not limited to the anthropogenic activities that have played a leading role throughout the degradation process. Those include paddy fields allowed

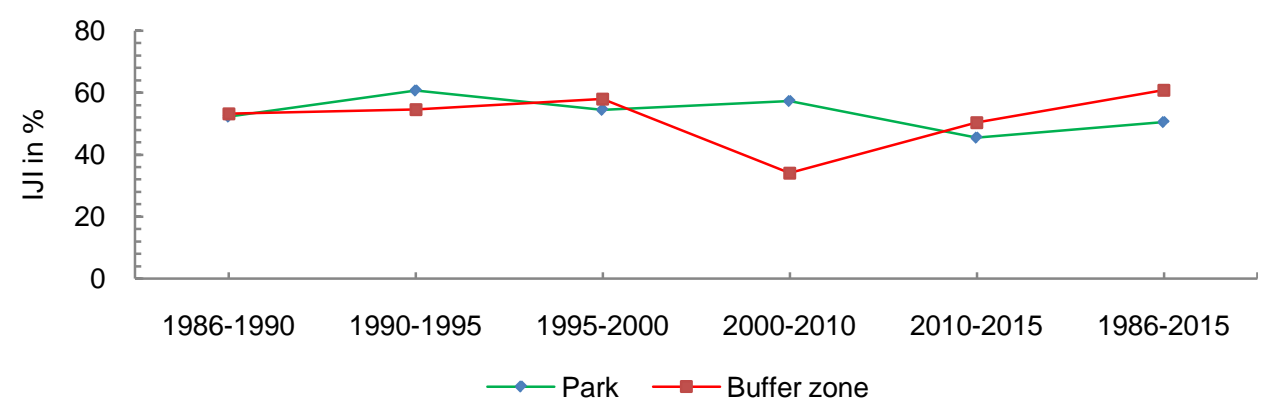

Figure 5. Variation of the IJI representing the spatial adjacency of forest cover type patches in-side the park and in buffer zone. 


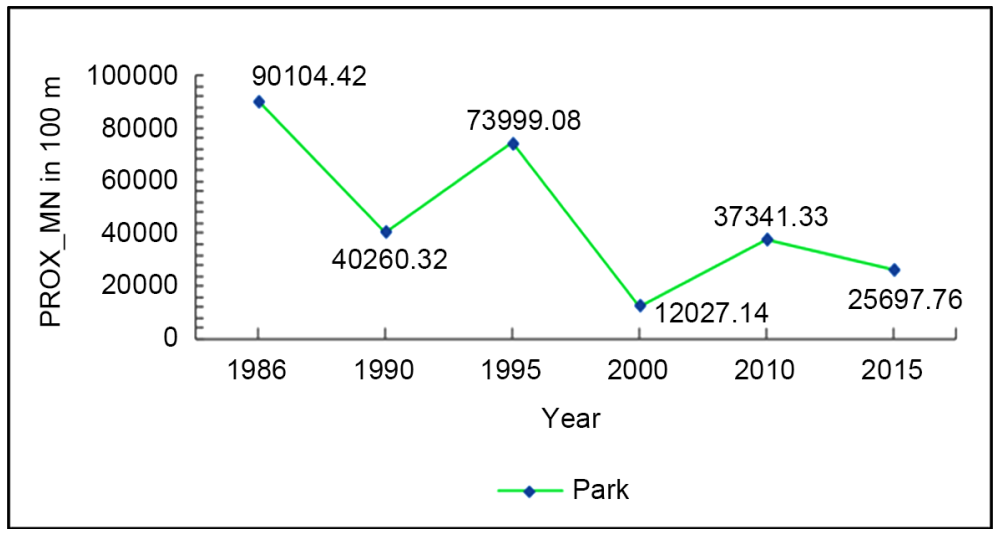

(a)

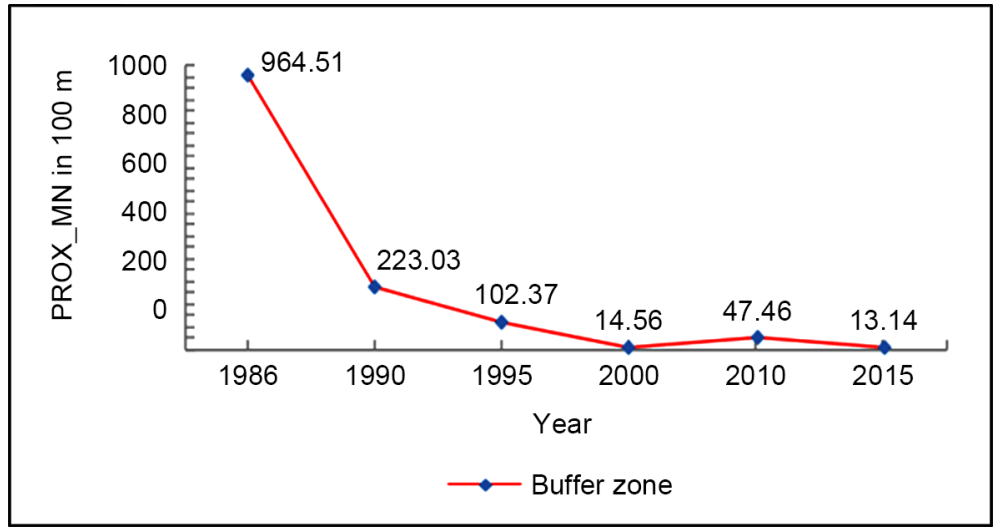

(b)

Figure 6. Mean Proximity index (PROX_MN) values showing the aggregation or clumping level of forest patches within radius distance of 100 meters (m). (a) PROX-MN forest aggregation changes within Park and (b) showing the aggregation change in buffer zone.

within the park, precisely in Kamiranzovu wetland as detailed by Masozera, M.K, et al. [47]; the national tarred roads creating edges such as the $52 \mathrm{Km}$ road linking the western and the southern provinces of Rwanda as well as the road linking Rwanda and Burundi, cutting through the forest [48]. In addition, it is worthwhile to note the stretching of tea croplands located in the region along the parks' outskirts which cause enormous pressure to the forest reserve where Rwegura, Teza, Rwabidege, Gisakura, Gisovu and Gabegi in Mudasomwa tea croplands showed a significant penetration into the park boundary (Figure 2). As reported by NICOLE, D. et al. [49], the impacts of agricultural dominance and the encroachment exerted on forest reserves were clearly illustrated by the statistics where approximately $90 \%$ of the households in Nyungwe buffer zone depend on agriculture for livelihoods and per capita wood demand for fuel amounted to at least $14,881 \mathrm{~kg} \mathrm{day}^{-1}$ which in turn affect the forest cover. Moreover, several analyses have been conducted on the sensitivity of forests with regards to the conflicts inflicted by the surrounding communities [50].

This study only dealt with the spatial and temporal pattern analysis and depicted the proximate forest changes within and outside the Park in a predetermined distance 
(buffer zone). The results discussed herein, land cover maps and statistical forest cover changes provided were not yet assessed and presented so far. Therefore, there is a great task for forest and Park management on both Rwandan and Burundian sides to effectively halt the degradation processes through joint collaboration and timely responses while promoting sustained research and mapping.

\section{Conclusion}

The forest cover changes and landscape dynamics within and outside Nyungwe-Kibira Park boundary were quantified and analyzed by means of remotely sensed data. This study provided deforestation/degradation and regeneration statistics at Nyungwe-Kibira Park and its buffer zone, in a period of 29 years (1986-2015). The results indicated that $180.18 \mathrm{Km}^{2}$ of forest cover within the Park were lost while the gained or regenerated forest extended over $35.43 \mathrm{Km}^{2}$. Also, a total of $412.08 \mathrm{Km}^{2}$ of forest cover were lost compared to $36.62 \mathrm{Km}^{2}$ of forest regenerated within $5 \mathrm{Km}$ buffer zone delineated outside the Park. The analysis of forest degradation using fragmentation measurement methods indicated a slight degradation inside the Park and the highest degradation outside the buffer zone. The high deforestation and the way that forest cover was greatly fragmented in the buffer zone directly reflect the dominance of agriculture around the park. This study has only focused on the spatial and temporal changes of forest cover without thoroughly delving into the driving forces of forest degradation. Nevertheless, previous researches as discussed above, clearly established the direct links between anthropogenic activities and forest degradation and how agriculture takes the lead when land conversions are targeted to maintain livelihoods as demonstrated in this paper. Therefore, this expresses the need for conservation efforts to be oriented towards this fact by promoting favorable measures such as the reduction of community dependencies and reforestation in the buffer zone. Finally, it is noted that the quantitative assessments of deforestation and degradation using spatial and temporal patterns constitute a valuable tool in terms of forest sustainability and management policies.

\section{Acknowledgements}

We would like to thank the United States Geological Survey and the NASA team for the provision of data. This research has been funded by the China-Africa Joint Research Centre Project of the Chinese Academy of Sciences, grant number: 2010DFB34020; National Natural Science Foundation of China (NSFC), grant number: 31570536 and The Volkswagen Foundation (Volkswagen Stiftung), grant number: Az.: 88497.

\section{References}

[1] Blaikie, P. and Brookfield, H. (2015) Land Degradation and Society. Routledge.

[2] Hartter, J., Ryan, S.J., Diem, J., Palace, M. and Chapman, C.A. (2012) Population, Environment, and Climate in the Albertine Rift: Understanding Local Impacts of Regional Change. AGU Fall Meeting Abstracts, p 0737.

[3] Houghton, R. (2012) Carbon Emissions and the Drivers of Deforestation and Forest De- 
gradation in the Tropics. Current Opinion in Environmental Sustainability, 4, 597-603. http://dx.doi.org/10.1016/j.cosust.2012.06.006

[4] Craigie, I.D., Baillie, J.E., Balmford, A., Carbone, C., Collen, B., Green, R.E. and Hutton, J.M. (2010) Large Mammal Population Declines in Africa's Protected Areas. Biological Conservation, 143, 2221-2228. http://dx.doi.org/10.1016/j.biocon.2010.06.007

[5] Miranda, J.J., Corral, L., Blackman, A., Asner, G. and Lima, E. (2016) Effects of Protected Areas on Forest Cover Change and Local Communities: Evidence from the Peruvian Amazon. World Development, 78, 288-307. http://dx.doi.org/10.1016/j.worlddev.2015.10.026

[6] Pfaff, A., Robalino, J., Herrera, D. and Sandoval, C. (2015) Protected Areas' Impacts on Brazilian Amazon Deforestation: Examining Conservation-Development Interactions to Inform Planning. PLoS One, 10, e0129460. http://dx.doi.org/10.1371/journal.pone.0129460

[7] Hockings, M. (2003) Systems for Assessing the Effectiveness of Management in Protected Areas. BioScience, 53, 823-832. http://dx.doi.org/10.1641/0006-3568(2003)053[0823:SFATEO]2.0.CO;2

[8] Sassen, M., Sheil, D., Giller, K.E. and Ter Braak, C.J. (2013) Complex Contexts and Dynamic Drivers: Understanding four Decades of Forest Loss and Recovery in an East African Protected Area. Biological Conservation, 159, 257-268.

http://dx.doi.org/10.1016/j.biocon.2012.12.003

[9] Tegegne, Y.T., Lindner, M., Fobissie, K. and Kanninen, M. (2016) Evolution of Drivers of Deforestation and Forest Degradation in the Congo Basin Forests: Exploring Possible Policy Options to Address Forest Loss. Land Use Policy, 51, 312-324.

http://dx.doi.org/10.1016/j.landusepol.2015.11.024

[10] Gebauer, C. and Doevenspeck, M. (2015) Adaptation to Climate Change and Resettlement in Rwanda. Area, 47, 97-104. http://dx.doi.org/10.1111/area.12168

[11] Heino, M., Kummu, M., Makkonen, M., Mulligan, M., Verburg, P.H., Jalava, M. and Räsänen, T.A. (2015) Forest Loss in Protected Areas and Intact Forest Landscapes: A Global Analysis. PLoS One, 10, e0138918. http://dx.doi.org/10.1371/journal.pone.0138918

[12] Ordóñez-Gómez, J.D., Cristóbal-Azkarate, J., Arroyo-Rodríguez, V., Santillán-Doherty, A.M., Valdez, R.A. and Romano, M.C. (2016) Proximal and Distal Predictors of the Spider Monkey's Stress Levels in Fragmented Landscapes. PLoS One, 11, e0149671. http://dx.doi.org/10.1371/journal.pone.0149671

[13] Plumptre, A., Ayebare, S. and Kujirakwinja, D. (2015) Priority Areas for Conservation in the Maiko, Tayna, Kahuzi Biega Landscape.

[14] Rutebuka, E., Nsabimana, D. and Gross-Camp, N. (2012) Evaluation of Community Based Conservation around Protected Areas in Rwanda, Nyungwe National Park.

[15] Masozera, M.K., Alavalapati, J.R., Jacobson, S.K. and Shrestha, R.K. (2006) Assessing the Suitability of Community-Based Management for the Nyungwe Forest Reserve, Rwanda. Forest Policy and Economics, 8, 206-216. http://dx.doi.org/10.1016/j.forpol.2004.08.001

[16] Midha, N. and Mathur, P. (2010) Assessment of Forest Fragmentation in the Conservation Priority Dudhwa Landscape, India Using Fragstats Computed Class Level Metrics. Journal of the Indian Society of Remote Sensing, 38, 487-500.

[17] Forsythe, K.W. and McCartney, G. (2014) Investigating Forest Disturbance Using Landsat Data in the Nagagamisis Central Plateau, Ontario, Canada. ISPRS International Journal of Geo-Information, 3, 254-273. http://dx.doi.org/10.3390/ijgi3010254

[18] del Castillo, E.M., García-Martin, A., Aladrén, L.A.L. and de Luis, M. (2015) Evaluation of Forest Cover Change Using Remote Sensing Techniques and Landscape Metrics in Moncayo Natural Park (Spain). Applied Geography, 62, 247-255. 
http://dx.doi.org/10.1016/j.apgeog.2015.05.002

[19] Gonzalez-Redin, J., Luque, S., Poggio, L., Smith, R. and Gimona, A. (2016) Spatial Bayesian Belief Networks as a Planning Decision Tool for Mapping Ecosystem Services Trade-Offs on Forested Landscapes. Environmental Research, 144, 15-26.

http://dx.doi.org/10.1016/j.envres.2015.11.009

[20] Barrell, J.P. (2016) Quantification and Spatial Analysis of Seagrass Landscape Structure through the Application of Aerial and Acoustic Remote Sensing.

[21] Bruggeman, D., Meyfroidt, P. and Lambin, E.F. (2016) Forest Cover Changes in Bhutan: Revisiting the Forest Transition. Applied Geography, 67, 49-66. http://dx.doi.org/10.1016/j.apgeog.2015.11.019

[22] Hansen, M.C., Krylov, A., Tyukavina, A., Potapov, P.V., Turubanova, S., Zutta, B., Ifo, S., Margono, B., Stolle, F. and Moore, R. (2016) Humid Tropical Forest Disturbance Alerts Using Landsat Data. Environmental Research Letters, 11, Article ID: 034008. http://dx.doi.org/10.1088/1748-9326/11/3/034008

[23] Chao, N., Mulindahabi, F. and Easton, J. Long Term Changes in Africa's Rift Valley: Impacts on Biodiversity and Ecosystems. Deborah Patrick, St. Vincent Hospital, Indianapolis, Indiana, USA, 147.

[24] Crawford, A. (2012) Conflict-Sensitive Conservation in Nyungwe National Park: Conflict Analysis. International Institute for Sustainable Development, Winnipeg, Manitoba, Canada.

[25] Ndahimana, M., Musonera, E. and Weber, M. (2013) Assessment of Marketing Strategies for Ecotourism Promotion: A Case of RDB/Tourism and Conservation in Rwanda. Journal of Marketing Development and Competitiveness, 7, 37-56.

[26] Nsabimana, D. (2009) Carbon Stock and Fluxes in Nyungwe Forest and Ruhande Arboretum in Rwanda. University of Gothenburg, Gothenburg.

[27] Ndayisaba, F., Guo, H., Bao, A., Guo, H., Karamage, F. and Kayiranga, A. (2016) Understanding the Spatial Temporal Vegetation Dynamics in Rwanda. Remote Sensing, 8, 129. http://dx.doi.org/10.3390/rs8020129

[28] Seimon, A. (2012) Climatology and Potential Climate Change Impacts in the Nyungwe Forest National Park, Rwanda.

[29] Shukla, B. and Patil, R. (2010) Overview of Grain Drying and Storage Problems in India. FAO Corporate Document Repository, 26.

[30] Nikolakopoulos, K.G., Kamaratakis, E.K. and Chrysoulakis, N. (2006) SRTM vs ASTER Elevation Products. Comparison for Two Regions in Crete, Greece. International Journal of Remote Sensing, 27, 4819-4838. http://dx.doi.org/10.1080/01431160600835853

[31] Africa, U. (2008) Atlas of Our Changing Environment. Division of Early Warning and Assessment (DEWA), UNEPU, Nairobi, Kenya.

[32] Hartter, J., Ryan, S.J., Southworth, J. and Chapman, C.A. (2011) Landscapes as Continuous Entities: Forest Disturbance and Recovery in the Albertine Rift Landscape. Landscape Ecology, 26, 877-890. http://dx.doi.org/10.1007/s10980-011-9616-0

[33] DeFries, R., Hansen, A., Newton, A.C. and Hansen, M.C. (2005) Increasing Isolation of Protected Areas in Tropical Forests over the Past Twenty Years. Ecological Applications, 15, 19-26. http://dx.doi.org/10.1890/03-5258

[34] Goldman, A., Hartter, J., Southworth, J. and Binford, M.W. (2008) The Human Landscape around the Island Park: Impacts and Responses to Kibale National Park. Cambridge University Press, Cambridge.

[35] Otukei, J.R. and Blaschke, T. (2010) Land Cover Change Assessment Using Decision Trees, 
Support Vector Machines and Maximum Likelihood Classification Algorithms. International Journal of Applied Earth Observation and Geoinformation, 12, S27-S31. http://dx.doi.org/10.1016/j.jag.2009.11.002

[36] Nurmemet, I., Ghulam, A., Tiyip, T., Elkadiri, R., Ding, J.-L., Maimaitiyiming, M., Abliz, A., Sawut, M., Zhang, F. and Abliz, A. (2015) Monitoring Soil Salinization in Keriya River Basin, Northwestern China Using Passive Reflective and Active Microwave Remote Sensing Data. Remote Sensing, 7, 8803-8829. http://dx.doi.org/10.3390/rs70708803

[37] Qamer, F.M., Shehzad, K., Abbas, S., Murthy, M., Xi, C., Gilani, H. and Bajracharya, B. (2016) Mapping Deforestation and Forest Degradation Patterns in Western Himalaya, Pakistan. Remote Sensing, 8, 385. http://dx.doi.org/10.3390/rs8050385

[38] Mcgarigal, K. (2015) FRAGSTATS Help. http://www.umass.edu/landeco/research/fragstats/documents/fragstats.help.4.2.pdf

[39] McGarigal, K. and Marks, B.J. (1995) Fragstats: Spatial Pattern Analysis Program for Quantifying Landscape Structure. General Technical Report PNW-GTR-351, USDA Forest Service, Pacific Northwest Research Station, Portland, Oregon, 134 p.

[40] Puyravaud, J.-P. (2003) Standardizing the Calculation of the Annual Rate of Deforestation. Forest Ecology and Management, 177, 593-596. http://dx.doi.org/10.1016/S0378-1127(02)00335-3

[41] Glennon, M.J. and Porter, W.F. (1999) Using Satellite Imagery to Assess Landscape-Scale Habitat for Wild Turkeys. Wildlife Society Bulletin, 27, 646-653.

[42] Sutthivanich, I. and Ongsomwang, S. (2015) Evaluation on Landscape Change Using Remote Sensing and Landscape Metrics: A Case Study of Sakaerat Biosphere Reserve (SBR), Thailand. International Journal of Environmental Science and Development, 6, 182-186. http://dx.doi.org/10.7763/IJESD.2015.V6.586

[43] Zhou, Q., Li, B. and Kurban, A. (2008) Spatial Pattern Analysis of Land Cover Change Trajectories in Tarim Basin, Northwest China. International Journal of Remote Sensing, 29, 5495-5509. http://dx.doi.org/10.1080/01431160802060938

[44] Bortoleto, L.A., Figueira, C.J.M., Dunning, J.B., Rodgers, J. and da Silva, A.M. (2016) Suitability Index for Restoration in Landscapes: An Alternative Proposal for Restoration Projects. Ecological Indicators, 60, 724-735. http://dx.doi.org/10.1016/j.ecolind.2015.08.002

[45] Lake Victoria Basin Commission (2013) Nyungwe-Kibira Transboundary Conservation Programme.

[46] Deguignet, M., Juffe-Bignoli, D., Harrison, J., MacSharry, B., Burgess, N. and Kingston, N. (2014) United Nations List of Protected Areas. UNEP-WCMC, Cambridge, UK.

[47] Masozera, M.K. and Alavalapati, J.R. (2004) Forest Dependency and Its Implications for Protected Areas Management: A Case Study from the Nyungwe Forest Reserve, Rwanda. Scandinavian Journal of Forest Research, 19, 85-92. http://dx.doi.org/10.1080/14004080410034164

[48] Elias, N. (2005) Road Edge Effect on Forest Canopy Structure and Epiphyte Biodiversity in a Tropical Mountainous Rainforest Nyungwe National Park, Rwanda. MSc. Thesis, International Institute for Geo-Information Science and Earth Observation, Netherlands.

[49] Gross-Camp, N.D., Martin, A., McGuire, S. and Kebede, B. (2015) The Privatization of the Nyungwe National Park Buffer Zone and Implications for Adjacent Communities. Society \& Natural Resources, 28, 296-311. http://dx.doi.org/10.1080/08941920.2014.948246

[50] Gapusi, J.R. (2007) Regeneration of Indigenous Species in Nyungwe Buffer Zone for Biodiversity Conservation and Local People's Livelihood in Rwanda. Swedish Biodiversity Centre, Uppsala University, Uppsala. 


\section{Appendix A}

Table 7. Matrices showing how the Land cover transitions occurred among the Land cover types within Nyungwe-Kibira Park and in buffer zone, (Unity: percentage (\%)).

\begin{tabular}{|c|c|c|c|c|c|c|c|c|c|c|}
\hline & \multicolumn{5}{|c|}{ Inside the Park } & \multicolumn{5}{|c|}{ In Buffer zone } \\
\hline & \multicolumn{10}{|c|}{1986} \\
\hline 1990 & 1 & 2 & 3 & 4 & 5 & 1 & 2 & 3 & 4 & 5 \\
\hline 1 & 71.15 & 4.42 & 0.32 & 0.06 & 0.02 & 3.97 & 0.00 & 0.00 & 0.00 & 0.00 \\
\hline 2 & 2.56 & 3.88 & 0.19 & 0.01 & 0.00 & 0.75 & 19.86 & 0.00 & 0.00 & 0.00 \\
\hline 3 & 4.44 & 4.56 & 6.92 & 0.05 & 0.02 & 0.37 & 2.69 & 71.72 & 0.00 & 0.00 \\
\hline 4 & 0.02 & 0.05 & 0.01 & 1.21 & 0.00 & 0.00 & 0.01 & 0.00 & 0.58 & 0.00 \\
\hline \multirow[t]{2}{*}{5} & 0.00 & 0.00 & 0.00 & 0.00 & 0.09 & 0.00 & 0.00 & 0.00 & 0.00 & 0.05 \\
\hline & \multicolumn{10}{|c|}{1990} \\
\hline 1995 & 1 & 2 & 3 & 4 & 5 & 1 & 2 & 3 & 4 & 5 \\
\hline 1 & 66.25 & 1.58 & 5.34 & 0.19 & 0.01 & 2.63 & 0.18 & 0.11 & 0.01 & 0.00 \\
\hline 2 & 6.75 & 4.56 & 2.17 & 0.09 & 0.00 & 0.70 & 16.23 & 2.53 & 0.18 & 0.00 \\
\hline 3 & 2.93 & 0.45 & 7.77 & 0.35 & 0.03 & 0.64 & 4.19 & 72.14 & 0.03 & 0.00 \\
\hline 4 & 0.15 & 0.07 & 0.56 & 0.65 & 0.00 & 0.00 & 0.01 & 0.01 & 0.37 & 0.00 \\
\hline \multirow[t]{2}{*}{5} & 0.03 & 0.00 & 0.02 & 0.00 & 0.05 & 0.00 & 0.00 & 0.00 & 0.00 & 0.04 \\
\hline & \multicolumn{10}{|c|}{1995} \\
\hline 2000 & 1 & 2 & 3 & 4 & 5 & 1 & 2 & 3 & 4 & 5 \\
\hline 1 & 65.40 & 7.19 & 3.64 & 0.18 & 0.01 & 1.41 & 2.00 & 3.77 & 0.00 & 0.00 \\
\hline 2 & 4.56 & 3.22 & 1.05 & 0.12 & 0.00 & 0.15 & 0.42 & 2.02 & 0.00 & 0.00 \\
\hline 3 & 3.32 & 3.15 & 6.50 & 0.45 & 0.04 & 1.35 & 17.04 & 71.19 & 0.07 & 0.00 \\
\hline 4 & 0.09 & 0.04 & 0.29 & 0.68 & 0.01 & 0.01 & 0.19 & 0.02 & 0.31 & 0.00 \\
\hline \multirow[t]{2}{*}{5} & 0.00 & 0.00 & 0.02 & 0.00 & 0.04 & 0.00 & 0.00 & 0.00 & 0.00 & 0.04 \\
\hline & \multicolumn{10}{|c|}{2000} \\
\hline 2010 & 1 & 2 & 3 & 4 & 5 & 1 & 2 & 3 & 4 & 5 \\
\hline 1 & 70.57 & 2.65 & 3.77 & 0.09 & 0.00 & 2.83 & 0.21 & 2.89 & 0.04 & 0.00 \\
\hline 2 & 4.81 & 5.64 & 3.22 & 0.10 & 0.00 & 0.99 & 0.32 & 6.10 & 0.12 & 0.00 \\
\hline 3 & 1.00 & 0.60 & 5.96 & 0.26 & 0.01 & 3.32 & 2.02 & 79.14 & 0.17 & 0.00 \\
\hline 4 & 0.06 & 0.06 & 0.46 & 0.65 & 0.00 & 0.04 & 0.04 & 1.54 & 0.20 & 0.00 \\
\hline 5 & 0.00 & 0.00 & 0.04 & 0.00 & 0.06 & 0.00 & 0.00 & 0.00 & 0.00 & 0.03 \\
\hline
\end{tabular}




\section{Continued}

\begin{tabular}{|c|c|c|c|c|c|c|c|c|c|c|}
\hline \multicolumn{11}{|c|}{2010} \\
\hline 2015 & 1 & 2 & 3 & 4 & 5 & 1 & 2 & 3 & 4 & 5 \\
\hline 1 & 58.82 & 3.45 & 1.29 & 0.19 & 0.01 & 1.25 & 0.32 & 0.73 & 0.00 & 0.00 \\
\hline 2 & 13.07 & 5.06 & 0.53 & 0.08 & 0.00 & 0.56 & 0.55 & 2.12 & 0.02 & 0.00 \\
\hline 3 & 6.21 & 4.14 & 5.50 & 0.46 & 0.07 & 4.16 & 6.65 & 81.71 & 0.57 & 0.00 \\
\hline 4 & 0.03 & 0.31 & 0.12 & 0.60 & 0.00 & 0.00 & 0.01 & 0.10 & 1.22 & 0.00 \\
\hline 5 & 0.00 & 0.00 & 0.00 & 0.00 & 0.05 & 0.00 & 0.00 & 0.02 & 0.00 & 0.03 \\
\hline & \multicolumn{10}{|c|}{1986} \\
\hline 2015 & 1 & 2 & 3 & 4 & 5 & 1 & 2 & 3 & 4 & 5 \\
\hline 1 & 61.65 & 1.98 & 0.18 & 0.02 & 0.00 & 0.82 & 0.72 & 0.73 & 0.01 & 0.00 \\
\hline 2 & 9.37 & 8.84 & 0.52 & 0.02 & 0.00 & 0.45 & 1.39 & 1.36 & 0.04 & 0.00 \\
\hline 3 & 6.00 & 2.92 & 7.16 & 0.17 & 0.04 & 3.79 & 20.10 & 68.84 & 0.35 & 0.01 \\
\hline 4 & 0.01 & 0.01 & 0.02 & 1.02 & 0.00 & 0.02 & 0.35 & 0.79 & 0.18 & 0.00 \\
\hline 5 & 0.00 & 0.00 & 0.00 & 0.00 & 0.06 & 0.00 & 0.00 & 0.01 & 0.00 & 0.04 \\
\hline
\end{tabular}

1: Dense Forest, 2: Dispersed and shrub, 3: Cultivated and Open land, 4: Perennial crop and 5: Water.

Submit or recommend next manuscript to SCIRP and we will provide best service for you:

Accepting pre-submission inquiries through Email, Facebook, LinkedIn, Twitter, etc.

A wide selection of journals (inclusive of 9 subjects, more than 200 journals)

Providing 24-hour high-quality service

User-friendly online submission system

Fair and swift peer-review system

Efficient typesetting and proofreading procedure

Display of the result of downloads and visits, as well as the number of cited articles

Maximum dissemination of your research work

Submit your manuscript at: http://papersubmission.scirp.org/

Or contact gep@scirp.org 